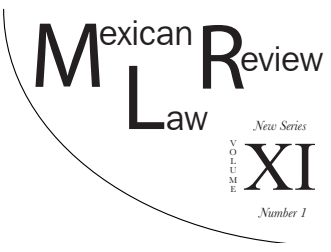

\title{
REFORMING MEXICO'S ANTI-TRAFFICKING IN PERSONS LEGISLATION
}

\author{
Guadalupe Correa-CabrerA* \\ Arthur SANDERS MONTANDON**
}

\begin{abstract}
In the past few years, Mexico has taken a number of measures to further prevention, protection, and prosecution of trafficking in persons. The country's government has signed international anti-trafficking conventions and has taken some aspects of widely accepted international definitions of this crime as a reference when drafting its anti-trafficking legislation. However, Mexican lawmakers have interpreted human trafficking in their own terms. Mexico's current anti-trafficking legislation is based on a quite broad definition of trafficking in persons and showes serious limitations that have led to the misidentification of victims and traffickers, as well as to re-victimization. This adds to Mexico's weak rule of law, corruption, and the involvement of interest groups with particular agendas/ideologies that have obstructed reform. The present analysis demonstrates the imperative necessity to modify the current anti-trafficking legislation in Mexico and provides some basic suggestions for this much-needed reform.
\end{abstract}

Keywords: Mexico, Palermo Protocol, human trafficking, anti-trafficking legislation, reform, Tapachula

Resumen: En los últimos años, México ha tomado una serie de medidas para prevenir, proteger y procesar judicialmente la trata de personas. Asimismo, el gobierno de este país ha suscrito convenciones internacionales anti-trata y ha

* Guadalupe Correa-Cabrera is Associate Professor at the Schar School of Policy and Government, George Mason University. She is also Global Fellow at the Woodrow Wilson International Center for Scholars (WWICS), Non-resident Scholar at the Baker Institute's Mexico Center (Rice University), and President of the Association for Borderlands Studies (ABS).Email: gcorrea75@gmail.com.

Arthur Sanders Montandon is a Master of Arts in Law and Diplomacy candidate at The Fletcher School at Tufts University. From 2016 to 2017, he worked as a research assistant at the WWICS. One preliminary version of the present article appeared on the Wilson Center's website as a working paper. Email: arthurmontandon@gmail.com. 
Esta revista forma parte del acervo de la Biblioteca Jurídica Virtual del Instituto de Investigaciones Jurídicas de la UNAM

adoptado aspectos clave de las definiciones de este delito ampliamente aceptadas en el ámbito internacional como referencia al diseñar su propia legislación. Sin embargo, algunos juristas mexicanos han interpretado el fenómeno de la trata de personas en sus propios términos. La legislación actual anti-trata se basa en una definición del fenómeno bastante amplia, que presenta serias limitaciones, las cuales han contribuido a una identificación errónea de víctimas y tratantes de personas, así como a la revictimización. Lo anterior se añade a la debilidad del estado de derecho en México, a la corrupción y al involucramiento de grupos de interés con agendas e ideologías especificas que han contribuido a obstruir una modificación de este marco legislativo. El presente análisis demuestra la imperativa necesitad de modificar la actual legislación anti-trata en México y provee algunas sugerencias básicas para realizar esta reforma tan necesaria.

Keywords: México, Protocolo de Palermo, trata de personas, legislación antitrata, reforma, Tapachula

\section{Table of Contents}

I. Preamble: A Field Trip to Tapachula, Ghiapas .............................. 5

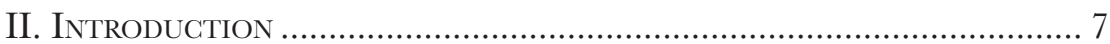

III. Mexico's Anti-Trafficking Legislative Framework ..................... 8

1. Defining Human Trafficking: Article 3 of the Palermo Protocol and the U.S. TVPA ................................................... 9

2. Mexico's 2007 Anti-Human Trafficking Law............................. 10

3. The Path towards the 2012 General Law .................................. 12

4. The 2012 General Law ............................................................. 13

IV. A Need to Reform Mexico’s Anti-Trafficking Legislation....... 15

1. Limitations of the 2012 Law ................................................. 15

A. A New Definition of Trafficking.......................................... 15

B. Increasing Numbers: Investigations, Convictions, and victims ................................................................. 16

C. Trafficking vs. Sexual Exploitation ........................................ 19

D. Trafficking and Irregular Migration ................................... 19

2. The Transition Towards an Oral Adversarial System................. 20

V. Tapachula And the EfFects of the 2012 General LaW ................. 22

VI. RECOMMENDATIONS FOR REFORM .................................................. 24

VII. Gonclusion........................................................................ 26

VIII. Appendix: Prostitution and Human Trafficking: a Historical Debate. 
Esta revista forma parte del acervo de la Biblioteca Jurídica Virtual del Instituto de Investigaciones Jurídicas de la UNAM

\section{Preamble: A Field Trip to Tapachula, Ghiapas}

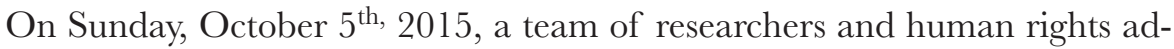
vocates visited the women's prison located in Tapachula, Chiapas, a city that is considered as one of the main sex trafficking hubs in Mexico. ${ }^{1}$ This visit was part of a field trip to study the role of transnational organized crime in human trafficking in Central America and along Mexico's eastern migration routes. ${ }^{2}$ The main goal of this visit was to interview women convicted of human trafficking crimes in order to understand their modus operandi, as well as their connection with other actors, including transnational criminal groups. We visited Tapachula since it is a well-known hub for human trafficking and particularly because it is located in Chiapas, a state that has in recent years received a number of domestic and international accolades and awards for the apparent progress it has made in terms of prevention, protection, and prosecution of trafficking in persons. For instance, Comisión Unidos vs. Trata (Commission United Against Human Trafficking), a non-governmental organization headed by former Congresswoman Rosa María Orozco, has recognized multiple times the current governor of Chiapas, Manuel Velasco Coello for his alleged significant contributions to preventing and prosecuting trafficking.

Most governmental and civil institutions lauding the state of Chiapas's anti-human trafficking efforts measure the state's success based on the increasing numbers of victims state authorities report having identified and rescued, as well as of perpetrators arrested and prosecuted. Since Chiapas created its Special Prosecutor's Office against Human Trafficking Crimes (Fiscalia Especializada en Atención a los Delitos en Materia de Trata de Personas), state authorities "have facilitated the rescue of 666 victims and brought 327 suspects to trial, achieving 85 convictions for human trafficking and 62 other sentences." ${ }^{3}$ One of the purposes of our field trip to Chiapas was to assess to what extent reality matched the promising statistics reported by the government.

In fact, what we witnessed on the ground differed starkly from the positive figures present in official speeches and reports. Of particular notice was the concerning situation faced by the inmates of the women's prison we visited in Tapachula. In the course of our interviews with eleven female prisoners charged and convicted of human trafficking, we became increasingly skepti-

1 The authors thank María Fernanda Machuca, who contributed to the present analysis and travelled to Tapachula to assist in the fieldwork.

2 This field trip was made possible by the generous support of the American people through the United States Department of State. The contents are the responsibility of the researchers and do not necessarily reflect the views of the Department of State nor the ones of the United States government.

3 General Prosecutor's Office of the State of Chiapas (PGJE), Participa Procuraduría de Chiapas en Encuentro Nacional en Materia de Trata de Personas, PGJE, (April 3, 2017, 11:45 AM), http://wrew.icosochiapas.gob.mx/2017/04/04/participa-procuraduria-de-chiapas-en-encuentro-nacionalen-materia-de-trata-de-personas/. 
Esta revista forma parte del acervo de la Biblioteca Jurídica Virtual del Instituto de Investigaciones Jurídicas de la UNAM

cal about the validity and consistency of the charges pressed against them. All the inmates we interviewed showed very high levels of vulnerability. Eight of them were migrants from Central America who did not know Mexico's territory and who were residing in the country for the first time. It is hard to envision any circumstances under which these women would be able to misguide, mislead or transport victims, and thus commit human trafficking. Their testimonies suggested that they were not leading any human trafficking ring in Mexico's southern border region. It was also clear that they were not the main beneficiaries of the very significant revenues that this industry generates in Tapachula. Some might have even been victims of this crime or might have been "in the wrong place at the wrong time."

Academic, governmental, civil society and media sources have often reported on the recurring abuses undocumented migrants endure in Mexico, including those experienced while in the custody of the Mexican government. Abusive employers, exploitative criminals, and corrupt state agents are known to threaten irregular migrants with deportation if they report abuses suffered at their hands. Due to their lack of familiarity with the local language and perceived fragility, foreign women, particularly indigenous girls and young women from Central America, are especially vulnerable to abuse by corrupt officials. The inmates we interviewed in Tapachula were young, female, impoverished, foreign, indigenous, and had low levels of formal education (some were illiterate). All these traits are vulnerability factors that increase a person's chances of falling victim to trafficking in the hands of criminal networks as well as victim of abuse by corrupt authorities. ${ }^{4}$ And in Mexico, where the federal government has been pressuring state governments to ramp up and improve their anti-trafficking records, this demographic group is particularly susceptible to falling victim to state authorities looking to illegitimately inflate their crime-fighting statistics.

Mexico's current anti-trafficking legislation is the main factor enabling Mexican states to arrest and jail individuals who are not actually traffickers. The legislation defines the crime in broader and vaguer terms than similar definitions adopted elsewhere, such as the ones adopted by the United Nations and the United States. This broader understanding of what constitutes trafficking allows Mexican law enforcement to characterize and prosecute a wide array of crimes as human trafficking, such as certain forms of prostitution, illegal adoption, and possession of child pornography. One example is the arrest in February 2014 and prosecution for human trafficking of Maria Alejandra Gil Cuervo, president of a Mexico City-based NGO whose mission was to promote HIV awareness among the city's sex workers. She was

4 On the conditions of vulnerability that facilitate human trafficking see Comisión Nacional de los Derechos Humanos (CNDH), and Centro de Estudios e Investigación en Desarrollo y Asistencia Social (CEIDAS), Diagnóstico de las condiciones de vulnerabilidad que propician la trata de personas en México, GNDH and CEIDAS (2009). 
Esta revista forma parte del acervo de la Biblioteca Jurídica Virtual del Instituto de Investigaciones Jurídicas de la UNAM

accused of leading a massive prostitution ring in Mexico City for over 30 years (Vela 2015). 5,6

Such flexibility and subjectivity in framing what constitutes trafficking in persons, combined with a weak rule of law and high levels of corruption, often spread, rather than prevent, injustice. Frequently, the individuals most affected by cases of miscarriage of justice engendered by the legislation's broad definition are society's most marginalized and vulnerable members, including trafficking victims themselves. The key leaders of human trafficking rings and main beneficiaries of related activities are often rich and powerful entrepreneurs and politicians who frequently escape arrest and other types of sanctions. Reforming Mexico's current anti-trafficking legislation and equipping the country's courts and law enforcement agencies with a definition that is in tune with international conventions is the first step towards enabling the country to prosecute criminals and protect victims efficiently while ensuring accountability. This study will present an overview of the process that led Mexico to its current anti-trafficking legislation, the law's shortcomings, and suggestions on how to amend them.

\section{INTRODUCTION}

Adopted by resolution A/RES/55/25 of November 15, 2000, the United Nations Protocol to Prevent, Suppress, and Punish Trafficking in Persons, Especially Women and Children (also known as the Trafficking Protocol, the Palermo Protocol, or U.N. TIP Protocol $)^{7}$ is a landmark international anti-human trafficking accord. ${ }^{8}$ It arose from the necessity to craft a comprehensive document that would define human trafficking and prescribe the actions its signatories should adopt. As a party to the protocol, Mexico adopted its first anti-trafficking law in November 2007.

Years later, in 2012, Mexico approved a revamped and broader anti-trafficking law that replaced its precursor. Mexican lawmakers also used the Pal-

5 Gil is currently serving a 15-year sentence in jail.

6 Vela, David Saúl, Sentencian a 15 años de cárcel a la 'Madame de Sullivan', EL Financiero, (Dec. 3, 2015, 2:35 PM), http://wrere.elfinanciero.com.mx/nacional/sentencian-a-15-anos-de-carcel-ala-madame-de-sullivan.html.

7 It entered into force on December 25, 2003. See United Nations, United Nations Convention against Transnational Organized Crime and the Protocols Thereto, United Nations, (Jul. 20, 2017, 10:30 PM), https://wrere.unodc.org/documents/treaties/UNTOC/Publications/TOC\%20Convention/ TOCebook-e.pdf.

8 The Palermo Protocol was initially intended to deal only with trafficking in women and children. However, it was subsequently expanded in scope to include all persons. Most states agree that particular attention should be given to the protection of women and children. See Anne Gallagher, Human rights and the new UN protocols on trafficking and migrant smuggling: $A$ preliminary analysis, 4 Human Rights QuARTERLy 23, 975-1004 (2001). 
Esta revista forma parte del acervo de la Biblioteca Jurídica Virtual del Instituto de Investigaciones Jurídicas de la UNAM

ermo Protocol as a reference while drafting the new legislation. However, Mexico defined human trafficking on its own terms. This divergence enables Mexican authorities to characterize a wider range of crimes and infractions as human trafficking. In some cases, individuals that did not commit a human trafficking crime according to the internationally accepted definition are prosecuted as traffickers in Mexico. The current broad definition of human trafficking considered in the Mexican legislation inhibits authorities from accurately identifying the source of this crime under different circumstances and from efficiently fighting this complex phenomenon.

The purpose of this article is to identify the drawbacks of the current antitrafficking legislation and to propose changes to the current framework that would allow: 1) the improvement of government authorities' interdiction of traffickers; 2) better identification of victims of trafficking, and 3) more effective international and intra-national efforts to combat human trafficking in Mexico. Overall, we believe that an improved legislative framework will further prevention, protection, and prosecution of human trafficking in the country.

This article provides a legal interpretation of the Palermo Protocol as a way to understand the international and widely accepted, even if imperfect, definition of trafficking in persons. The first part of this analysis explains the changes in Mexico's anti-human trafficking legislation and examines its current contents in contrast with the U.S. legislation and the Palermo Protocol. Overall, the present article assesses the divergence between the definition of trafficking in international and Mexican provisions and laws. It also explains which groups supported Mexico's definition of trafficking in persons and for what reasons, and it describes the impacts that current legislation has had on anti-trafficking efforts in Mexico. This article highlights the limitations of Mexico's legislation and the serious obstacles it poses today to further prevention, protection, and prosecution of trafficking in persons in the country. These problems are illustrated by analyzing in depth the case of Tapachula, Chiapas. Finally, the present article provides suggestions for reform and highlights policy directions that might have a favorable impact on investigations, prosecutions, and convictions related to this high-level crime.

\section{Mexico’s Anti-Trafficking Legislative Framework}

The recruitment, transportation, transfer, harboring or receipt of persons, by means of the threat or use of force or other forms of coercion, of abduction, of fraud, of deception, of the abuse of power or of a position of vulnerability or of the giving or receiving of payments or benefits to achieve the consent of a person having control over another person, for the purpose of exploitation.

- U.N. definition of trafficking in persons 
Esta revista forma parte del acervo de la Biblioteca Jurídica Virtual del Instituto de Investigaciones Jurídicas de la UNAM

\section{Defining Human Trafficking: Article 3 of the Palermo} Protocol and the U.S. TVPA

The U.N. TIP Protocol or Palermo Protocol defines human trafficking in subparagraph (a) of its Article 3. According to the text, for a crime to be labeled as human trafficking, it should include three basic elements: acts, means, and purpose. Hence, an observer trying to determine if a crime constitutes human trafficking has to identify three main components:

1. The acts, or in other words, what happened. Subparagraph (a) lists the following acts: "recruitment, transportation, transfer, harboring or receipt of persons." However, those acts alone are insufficient to classify the crime as trafficking in persons.

2. The means, or how the acts listed above were carried out, are just as important. The Protocol specifies the following set of means: "threat or use of force or other forms of coercion, of abduction, of fraud, of deception, of the abuse of power or of a position of vulnerability or of the giving or receiving of payments or benefits to achieve the consent of a person having control over another person."

3. Finally, human trafficking crimes must not only consist of the acts listed above and be performed by using the described means. Exploitation should be the purpose of those acts. In other words, why the crime happened is just as important as what happened and how it happened.

A legal interpretation of the Palermo Protocol would state that for a crime to be considered human trafficking, these three elements must be present. Thus, if an individual (or group of individuals) commit(s) one or more of the listed acts for the purpose of exploiting someone, but do(es) not do so by using at least one of the means described, he/she is certainly infringing on the rights of his/her victim, and committing a crime. However, that crime, as heinous as it may be, is not human trafficking. "If one of these elements is absent, we are not facing trafficking in persons, we are facing a different crime, or just an administrative fault, or the violation of labor rights." ${ }^{9}$ The Trafficking Protocol provides only one exception when one of the elements, namely the means, does not need to be present for a crime to be classified as human trafficking. Subparagraphs (c) and (d) note that when the victim is under eighteen years of age, the acts described, when performed for the purpose of exploitation, constitute human trafficking, "even if this does not involve any of the means set forth in subparagraph (a)."

Also in 2000, the United States enacted the Victims of Trafficking and Violence Protection Act (TVPA), which states that "severe forms of trafficking in persons means: (a) sex trafficking in which a commercial sex act is induced by

9 Hispanics in Philanthropy (HIP), Una mirada desde las organizaciones de la sociedad civil a la trata de personas en México, HISPANICS IN PHILANTHROPY, 10 (2017). 
Esta revista forma parte del acervo de la Biblioteca Jurídica Virtual del Instituto de Investigaciones Jurídicas de la UNAM

force, fraud, or coercion, or in which the person induced to perform such act has not attained 18 years of age; or (b) the recruitment, harboring, transportation, provision, or obtaining of a person for labor or services, through the use of force, fraud, or coercion for the purpose of subjection to involuntary servitude, peonage, debt bondage, or slavery." There are differences between the TVPA and the Palermo Protocol, but they similarly recognize the three key elements of human trafficking: acts, means, and purpose.

It is worth noting that even these widely accepted definitions of human trafficking have been contested at several levels and by several actors. According to Sienna Baskin, Director of the Anti-Trafficking Fund, "the question of defining trafficking is actually quite complex." She explains that the "U.N. TIP protocol is the result of much struggle and compromise, producing vague concepts like 'the exploitation of prostitution of a person'." ${ }^{10}$ In her view, "the U.S. definition is different but similarly contested. For example, it does not include organ trafficking. It changed recently to define a person who offers to pay a minor for sex as a trafficker." It is thus important to acknowledge that these are contested definitions, "different from jurisdiction to jurisdiction, that draw a circle around certain acts and leave other acts, which some might see as equally abusive, out." ${ }^{11}$ Notwithstanding the different interpretations of what constitutes human trafficking, the United Nations Office on Drugs and Crime (UNODG) provides a model law as a template for countries to draft their own regulations. ${ }^{12}$

\section{Mexico's 2007 Anti-Human Trafficking Law}

Mexico signed the Palermo Protocol in late 2000. This was the first step the Mexican government took in recognizing trafficking in persons as a domestic and international issue. Concurrently with the Congress's deliberations on anti-trafficking legislation, the Office of the United Nations High Commissioner for Human Rights (OHCHR) pressured Mexico to improve its treatment of foreign-born trafficking victims. As noted in the final report of Mexico's TIP Shelter Project, ${ }^{13}$ before 2006 the Mexican government did not provide protection or social assistance to foreign victims who were in Mexico irregularly. ${ }^{14}$ Additionally, the government often deported these victims. This

10 On such a compromise, see Appendix 1.

11 Sienna Baskin, e-mail message to author and others (Mar. 21, 2017).

12 See United Nations Office on Drugs and Crime (UNODG), Model Law against Trafficking in Persons, UNODC, (Jul. 20, 2009, 3:50 PM), https://wrere.unodc.org/documents/human-trafficking/ UNODC_Model_Law_on_Trafficking_in_Persons.pdf.

13 This project was known as PROTEJA Shelter Project. PROTEJA stands for Proyecto de Apoyo a Refugios para Victimas de Trata de Personas en México (in English: PROTECT - Project to Support Shelters for Victims of Human Trafficking in Mexico).

14 PROTEJA was a program focused on improving shelters for migrants and human trafficking victims in Mexico. It received funding from USAID under the President's Initiative 
Esta revista forma parte del acervo de la Biblioteca Jurídica Virtual del Instituto de Investigaciones Jurídicas de la UNAM

ran contrary to the directives set forth by the U.N. TIP Protocol that requires its parties to protect the basic human rights of all trafficking victims. And, in pragmatic terms, the deportation of foreign victims deprived Mexican courts of important witnesses, without whom prosecuting traffickers becomes a significantly harder task. Since then, Mexico's National Migration Institute (INM) shifted its policy towards foreign victims of trafficking. The INM now grants foreign trafficking victims temporary resident visas and working permits for the duration of the judicial process against their alleged traffickers.

Mexico ratified the Palermo Protocol in March 2003, and in 2004 the Mexican Congress discussed drafting national anti-trafficking laws. On December 9, 2004, senators Enrique Jackson Ramírez, Ramón Mota Sánchez, and Miguel Sadot Sánchez Carreño (all affiliated with the Institutional Revolutionary Party, PRI) formally presented a proposed anti-human trafficking law. On November 27, 2007, Mexico published its first anti-trafficking law in the Official Gazette (Diario Oficial de la Federación, DOF): the "Law to Prevent and Punish Trafficking in Persons" (Ley para Prevenir y Sancionar la Trata de Personas).

Ten pages long, the text of the first Mexican anti-trafficking law was relatively short. It provided a definition of human trafficking that followed the language present in the Palermo Protocol. The first paragraph of its Article 5 presented and described all three elements discussed in the Protocol: acts, means, and purpose of trafficking; it also defined organ trafficking as human trafficking. The paragraph read: "commits human trafficking those who promote, procure, provide, facilitate, obtain, transfer, deliver, or receive a person, either for himself or others, by means of physical or moral violence, deceit or abuse of power, for the purpose of sexual exploitation, forced labor or services, slavery or practices analogous to slavery, servitude, or the removal of an organ, tissue, or one of his components."15

The second and last paragraph of Article 5 mirrors subparagraphs (c) and (d) of the Protocol's Article 3 when stating that: "when this crime is committed against people under the age of eighteen years old, or against those who are not capable of comprehending the significance of the act committed, or those who are not capable of resisting it, the verification of the means of trafficking will not be required." Thus, only if the victim is a minor, or someone incapable of giving consent, a crime that has the acts and purpose, but not the means, described by the law will be classified as trafficking.

to Combat Trafficking in Persons. It was comprised of 127 civil society organizations and 95 government agencies. See Capable Partners Program-Mexico, Mexico's TIP Shelter Project, Final Report, May 2006-Mar. 2009, USAID (2010).

15 See Chamber of Deputies, Ley para Preveniry Sancionar la Trata de Personas, Última Reforma DOF 01-06-2011, Government of MeXico (Feb. 20, 2016, 4:40 PM). http://werere.inegi. org.mx/est/contenidos/proyectos/aspectosmetodologicos/clasificadoresycatalogos/ced2012/doc/federal/ LPPYSLTDP.pdf. 
Esta revista forma parte del acervo de la Biblioteca Jurídica Virtual del Instituto de Investigaciones Jurídicas de la UNAM

It is also worth noting that Article 10 of Mexico's 2007 anti-trafficking law postulated that the federal government would establish a permanent interagency commission to study the phenomenon of trafficking in persons. The Commission would be responsible for formulating a national program to prevent and combat human trafficking. It would also be responsible for fostering cooperation between the federal and state governments, as well as for coordinating anti-trafficking efforts.

\section{The Path Towards the 2012 General Law}

On February 27, 2009, the executive branch issued the enabling legislation (reglamento) of the 2007 law that directed and informed states how to interpret and apply the new anti-trafficking legislation in Mexico. It also delineated with further detail how the newly created interagency commission would function. In December 2009, a federal judge used the 2007 law to sentence human traffickers for the first time. ${ }^{16}$ In August 2010, the Permanent Commission of the Mexican Congress (Comisión Permanente del Congreso de la Unión) proposed that state anti-trafficking laws should be updated to be consistent with international and federal laws. ${ }^{17}$ On January 6, 2011, the Inter-secretarial Commission to Prevent and Sanction Human Trafficking published its national program in the Official Gazette (DOF). ${ }^{18}$ The program had as its four core objectives: to know the current context, causes, and consequences of human trafficking in Mexico; to prevent the crime of human trafficking; to assist in the improvement of law enforcement in regards to human trafficking; and to provide comprehensive and high quality care to people in situations of trafficking, as well as to relatives and witnesses.

The document operationalized the four objectives with variables such as the number of anti-trafficking campaigns, the number of federal-state antitrafficking cooperation agreements, and the number of victims treated. It presented what the situation was in Mexico in 2010 and where the government should be in 2012. In 2011, out of Mexico's 32 states (including the capital city), 28 states and the Federal District (now Mexico City) had defined human trafficking as a crime in their jurisdictions. Among these states, only 13 had laws on how to provide support to trafficking victims. ${ }^{19}$

16 U.S. Department of State, Trafficking in Persons Report, U.S. Department of State (2010).

17 Animal Político (staff), Propone Congreso reformar leyes contra trata de personas, ANIMAL POLÍTICO, (Aug. 26, 2010, 3:15 PM), http://wrewe.animalpolitico.com/2010/08/el-congreso-propone-reformascontra-la-trata-de-personas/.

18 See Secretaría de Gobernación (SEGOB), Programa Nacional para Prevenir y Sancionar la Trata de Personas 2010-2012, Comisión Intersecretarial para Prevenir y Sancionar la Trata de Personas, Diario Oficial de la Federación, SEGOB (2011).

19 Patricia Guillén, Trata de personas, segundo ilícito más redituable en México, Animal Político, (Abril 13, 2011, 7:24 AM), http://wwre.animalpolitico.com/2011/04/trata-de-personas-segundoilicito-mas-redituable-en-mexico/. 
On March 15, 2011, the Federal Chamber of Deputies agreed, with 401 votes in favor, to reform the 2007 federal law. ${ }^{20}$ One of the main reasons for such a reform is that it was extremely difficult to prove that trafficking took place. Particularly difficult to prove was the subjugation of a person by means of coercion, abduction, fraud, deception, or any other element that was then stipulated in the law. "This was the main argument used to establish that the 2007 law did not work to detain the person who was actually benefiting from trafficking in persons. To prove the subjugation was a big challenge."${ }^{, 21}$ At the same time, it was contended that the existing law did not provide enough provisions to assure the victim's safety. The new law would classify human trafficking as a serious felony, thus allowing judges to issue preventive arrest warrants against suspected traffickers. In August 2011, lawmakers presented the text of the updated legislation to Congress.

Some anti-prostitution NGOs, known as "abolitionists" due to their opposition to prostitution and their advocacy to outlaw this activity, saw a significant opportunity in the reform. These groups tend to equate prostitution with human trafficking. The legality of prostitution in Mexico makes it difficult to determine whether the alleged trafficked victim is engaged in commercial sex activities willingly or if a third person is forcing and/or exploiting him/her. ${ }^{22}$ Abolitionists believe that every person participating in the sex trade does so involuntarily, and in their view, "it is not necessary to prove how she/he is retained. By eliminating the need to prove the subjugation, it would be much easier to demonstrate the existence of human trafficking." These arguments were crucial in the push to eliminate "the means" from the definition of trafficking in persons in the new law of $2012 .{ }^{23},{ }^{24}$

\section{The 2012 General Law}

On June 14, 2012, the General Law to Prevent, Sanction and Eradicate Crimes Related to Trafficking in Persons was published in the Official Gazette (DOF). ${ }^{25}$ Its stated goal was to better articulate and delineate how fed-

20 See voting in: http://gaceta.diputados.gob.mx/Gaceta/Votaciones/61/tabla2or2-44.php3 (Parliamentary Gazette, LXI Legislature, Chamber of Deputies, Mexico City).

21 Hispanics in Philanthropy (HIP), Una mirada desde las organizaciones de la sociedad civil a la trata de personas en México, Hispanics in Philanthropy, 10 (2017).

22 Ibid, 11.

23 Ibid, 11.

24 See Appendix 1 for a discussion on the divide between abolitionist and non-abolitionist views of prostitution and the impact of these views on the concept of human trafficking.

25 It is officially called General Law to Prevent, Sanction and Eradicate Crimes Related to Trafficking in Persons and for the Protection and Assistance of Victims of these Crimes (Ley General para Prevenir, Sancionar y Erradicar los Delitos en Materia de Trata de Personas y para la Protección y Asistencia a las Víctimas de estos Delitos). 
Esta revista forma parte del acervo de la Biblioteca Jurídica Virtual del Instituto de Investigaciones Jurídicas de la UNAM

eral, state, and municipal authorities should act and cooperate in their antitrafficking efforts. In contrast to its 10-page predecessor, lawmakers intended that the General Law's 129 articles, spreading 48 pages, would clearly define human trafficking and provide assurances to its victims. ${ }^{26}$ The legislation's most visible proponents declared that the new law would allow the government to fight trafficking more efficiently. ${ }^{27}$

The new anti-trafficking legislation was accompanied by constitutional reforms. For example, changes were made to Article 20 of the Mexican Constitution so that human trafficking victims could have their identities and personal information kept secret. Article 73 of Mexico's Carta Magna was also modified in order to accommodate a more detailed anti-trafficking law. ${ }^{28}$ While the 2007 legislation prescribed six to 18 years of imprisonment to traffickers, the new legislation increased the penalties to a maximum of 40 years behind bars, depending on the form of trafficking committed. ${ }^{29}$

While the 2007 law focused on human trafficking as an international crime, allowing states to use discretion on how they would prosecute traffickers, the new law framed human trafficking as a domestic crime. ${ }^{30}$ In other words, the 2012 legislation shifted the focus from international to domestic trafficking. The 2007 law understood trafficking as essentially happening when a victim was brought from a foreign country. ${ }^{31}$ The current law understands it at the domestic level as well, meaning that if someone was misled or abducted and brought from one Mexican state to another, that constitutes trafficking. It is worth noting that when the focus shifted to the domestic level, the number of people the government identified astraffickers increased significantly.

The 2012 General Law was a more complex and comprehensive law than the one approved in 2007. It also significantly changed Mexico's definition of human trafficking. The first law clearly stated that for a crime to be hu-

26 See Chamber of Deputies, Ley General para Prevenir, Sancionar y Erradicar los Delitos en Materia de Trata de Personas y para la Protección y Asistencia a las Victimas de estos Delitos, Última Reforma DOF 19-03-2014, Government of Mexico (Feb. 20, 2014, 6:30 PM). http://wrwrediputados.gob. $m x /$ LeyesBiblio/pdf/LGPSEDMTP.pdf.

27 Aprueban diputados ley contra trata de personas, ANIMAL POLÍTICO, (May 14, 2017, 4:07 PM), http://wwre.animalpolitico.com/2012/03/aprueban-diputados-ley-contra-trata-de-personas/.

28 Promulga Calderón reforma contra trata de personas, ANIMAL POLítico, (May 21, 2017, 3:58 PM), http://wrwe.animalpolitico.com/2011/07/promulga-calderon-reforma-contra-trata-de-personas/.

29 Diputados aprueban sanción de hasta 40 años a quien cometa trata de personas, ANimal Político, (May 22, 2017, 7:25 PM), http://wrwre.animalpolitico.com/2012/04/diputados-aprueban-sancion-dehasta-40-anos-a-quien-cometa-trata-de-personas/.

30 Francisco Sandoval Alarcón, Diputados congelan ley para castigar la trata de personas, ANIMAL Político, (Diciembre 28, 2011, 8:29 AM), http://wwer.animalpolitico.com/2011/12/diputadoscongelan-ley-para-castigar-la-trata-de-personas/.

31 For example, under the 2007 law, if someone was a foreigner and worked in the sex industry, the government tended to consider her/him to be a victim of trafficking and those in charge of her to be traffickers. The government disregarded that foreign migrants might choose to work in the sex industry in order to finance their travel towards the United States. 
man trafficking, it had to include all three elements of trafficking, that is, acts, means, and purpose. The second law understands that for a crime to be classified as human trafficking, it suffices to prove that a set of acts was performed for the purpose of benefiting from exploiting people, regardless of how these acts were performed. Article 10 of the General Law considers the means (i.e. force, threat, coercion, and fraud) as aggravating factors, but not basic elements of human trafficking. This small but important change made the Mexican definition of human trafficking pointedly broader than the definitions set forth in the Palermo Protocol and the U.S. anti-trafficking legislation. ${ }^{32}$ It is worth noting that eliminating the means from the definition of human trafficking is not a widespread phenomenon in other regions of the world. Of the 188 countries with human trafficking laws and a specific anti-trafficking institutional framework, less than a dozen have eliminated the means as a key provision for the occurrence of trafficking in persons.

\section{A Need to Reform Mexico’s Anti-Trafficking Legislation}

\section{Limitations of the 2012 Law}

\section{A. A New Definition of Trafficking}

In sum, whereas under the U.N. TIP Protocol, acts, means, and purpose are the three elements of human trafficking, Mexico's 2012 trafficking law eliminates the means and only considers acts and purpose as the key elements of trafficking in persons. By removing the means, trafficking becomes one of many forms of exploitation. The first paragraph of Article 10 is the one that resembles the most basic contents of the Palermo Protocol, but the article's subsections then start to define and regulate what entails exploitation instead of focusing on trafficking. Specifically, Article 10 of the 2012 law defines trafficking to include: slavery, serfdom, prostitution and other forms of sexual exploitation (such as table dancing), labor exploitation, ${ }^{33}$ forced labor, the use of children for organized crime, forced begging, illegal adoption, forced or servile marriage, the trafficking of organs and unlawful biomedical research on humans. ${ }^{34}$ Article 14 of the current law also defines the production, distribution, and possession of pornography as a form of trafficking. ${ }^{35}$

32 U.S. Department of State, Trafficking in Persons Report, U.S. Department of State (2015).

33 It is worth noting that the concept of labor exploitation is quite broad and unless we are talking about forced labor, this phenomenon cannot be considered strictly human trafficking.

34 Chamber of Deputies, Ley General para Prevenir, Sancionar y Erradicar los Delitos en Materia de Trata de Personas y para la Protección y Asistencia a las Victimas de estos Delitos, Última Reforma DOF 19-03-2014, Government of Mexico, Article 10, 7 (Feb. 20, 2014, 6:30 PM). http://wrere. diputados.gob.mx/LeyesBiblio/pdf/LGPSEDMTP.pdf.

35 Ibid. Article 14, 8. 
Esta revista forma parte del acervo de la Biblioteca Jurídica Virtual del Instituto de Investigaciones Jurídicas de la UNAM http://www.juridicas.unam.mx/

DOI: http://dx.doi.org/10.22201/iij.24485306e.2018.1.12509

B. Increasing Numbers: Investigations, Convictions, and Victims

Overall, this new broad definition of trafficking allows for an expansion beyond the Protocol's categories of "sexual exploitation, forced labor, slavery and its practices, servitude, and the removal of organs" (U.N. TIP Protocol 2000, Article 3). The definition of trafficking under the 2012 law also extends beyond the U.S. TVPA. This change has had a direct impact on how human trafficking has been prosecuted in Mexico since 2012. The broader definition of human trafficking increased the number of human trafficking cases that the Mexican government has investigated, as well as the number of convictions for this crime (see Tables 1 and 2).

\section{TABLE 1}

FEDERAL AND STATE INVESTigations, HUMAN TRAFFicking CASES

(2008-2016)

\begin{tabular}{|l|l|c|}
\hline \multicolumn{1}{|c|}{ Year } & \multicolumn{1}{|c|}{ Federal Investigations } & State Investigations \\
\hline 2008 & 24 (FEVIMTRA) & N/A \\
\hline 2009 & 48 & N/A \\
\hline 2010 & 76 (FEVIMTRA) + N/A SIEDO & N/A \\
\hline 2011 & 67 (FEVIMTRA) & N/A \\
\hline 2012 & 72 (FEVIMTRA) + 21 (UEITMPO) & N/A \\
\hline 2013 & 91 (FEVIMTRA) +48 (SEIDO) & 196 \\
\hline 2014 & 253 & 415 \\
\hline 2015 & 250 & 288 \\
\hline 2016 & 188 & N/A \\
\hline
\end{tabular}

Source: U.S. Department of State, Trafficking in Persons Report, U.S. Department of State (2009-2017). The information for each year is reported in the DOS TIP report of the following year.

Notes: Prior to 2015, the DOS TIP reports did not register the number of state investigations opened per year. Starting in 2015, the DOS TIP reports stopped distinguishing between FEVIMTRA and federal investigations by other agencies (SEIDO; UEITMPO, and SIEDO). SEIDO stands for Subprocuraduría Especializada en Investigación de Delincuencia Organizada (Deputy Attorney-General's Office Specialized on Investigations on Organized Crime); UEITMPO is Unidad Especializada en Investigación de Tráfico de Menores, Personas y Órganos (Special Prosecution Unit on Investigations of Trafficking in Minors, Persons and Organs); and SIEDO stands for Subprocuraduría de Investigación Especializada en Delincuencia Organizada (Deputy Attorney-General's Office for Special Investigation on Organized Crime). 
Esta revista forma parte del acervo de la Biblioteca Jurídica Virtual del Instituto de Investigaciones Jurídicas de la UNAM

TABLE 2

Convictions, HUMAN TRAFFicking CASES (2009-2016)

\begin{tabular}{|c|c|c|}
\hline Year & Federal & State \\
\hline 2009 & 0 & 22 \\
\hline 2010 & 1 & 49 \\
\hline 2011 & 4 & 65 \\
\hline 2012 & 0 & 68 \\
\hline 2013 & 2 & 154 \\
\hline 2014 & 8 & 137 \\
\hline 2015 & 4 & 123 \\
\hline Total & 19 & 618 \\
\hline
\end{tabular}

Source: Secretaría de Gobernación (SEGOB), Informe Anual de la Comisión Intersecretarial para Prevenir, Sancionar y Erradicar los Delitos en Materia de Trata de Personas 2015, SEGOB (2016). For the years 2009-2015. "Local" convictions were decided at the High Court of Justice of the states (Tribunal Superior de Fusticia) and "federal" convictions at the Judicial Power of the Federation (Poder Fudicial de la Federación). This table shows the number of convictions for the years 20092013. The present document does not show the number of investigations conducted during those years since they were not included in the DOS TIP reports and because some inconsistencies were found in the available sources.

The number of identified victims also increased significantly (see Table 3). Mexican authorities identified 35 victims of human trafficking in the country in 2010 - considering both federal and local cases. In 2015, that number rose to $439 .{ }^{36}$ In July 2015, news website Animal Politico reported that the number of human trafficking complaints increased $600 \%$ between 2008 and $2014 .^{37}$ In 2015, the number of federal investigations of human trafficking cases did not shift significantly from the previous year, decreasing from 253 to 250 . On the other hand, state investigations more than doubled during the same year - from 196 to 415 new state investigations. ${ }^{38}$ In 2016, both federal and state investigations decreased. During this year, Mexico's government "decreased overall funding for investigations and prosecutions," impeding its ability to investigate and prosecute human trafficking crimes. ${ }^{39}$

36 Secretaría de Gobernación (SEGOB), Informe Anual de la Comisión Intersecretarial para Prevenir, Sancionar y Erradicar los Delitos en Materia de Trata de Personas 2015, SEgOB (2016).

37 Arturo Ángel, Las denuncias por trata de personas se disparan 600\% en México en 6 años, ANIMAL POLÍTico, (May 21, 2017, 7:23 AM), http://wrere.animalpolitico.com/2015/07/las-denuncias-portrata-de-personas-se-disparan-600-en-mexico-en-6-anos/.

38 See: Table 1, U.S. Department of State, Trafficking in Persons Report, U.S. Department of STATE (2016).

39 U.S. Department of State, Trafficking in Persons Report, U.S. Department of State (2017). 
Esta revista forma parte del acervo de la Biblioteca Jurídica Virtual del Instituto de Investigaciones Jurídicas de la UNAM

TABLE 3

Number OF VICTIMS OF HUMAN TRAFFICKING (2009-2016)

\begin{tabular}{|c|c|c|}
\hline Year & Federal & State \\
\hline 2009 & 0 & 25 \\
\hline 2010 & 8 & 27 \\
\hline 2011 & 9 & 107 \\
\hline 2012 & 0 & 127 \\
\hline 2013 & 5 & 211 \\
\hline 2014 & 8 & 271 \\
\hline 2015 & 19 & 420 \\
\hline Total & 49 & 1,218 \\
\hline
\end{tabular}

SOURCE: Secretaría de Gobernación (SEGOB), Informe Anual de la Comisión Intersecretarial para Prevenir, Sancionar y Erradicar los Delitos en Materia de Trata de Personas 2015, SEGOB (2016).

The broader definition of human trafficking present in the 2012 General Law is not the only element that explains the increase of human trafficking investigations, identified victims, and complaints in the past few years in Mexico. Since 2004 Mexico has undertaken significant efforts to improve its laws, educate law enforcement agencies and judges on the nature of human trafficking, and raise awareness. Nevertheless, the adverse effects of Mexico's current definition of trafficking in persons must be acknowledged. For example, this broader definition seems to have led to a number of people, who would not be considered as traffickers under the international definition, to be prosecuted as traffickers in Mexico.

What is more, under Mexico's current legislative framework, "many other offenses that are not trafficking, but are related to it, are now punishable alongside trafficking. These include: purchasing sex while being aware that the person is trafficked, renting a building knowing it will be utilized for trafficking, and posting advertisements with trafficking ends" ${ }^{40}$ In fact, under the current Mexican anti-trafficking law, if you benefit from the exploitation or are aware of the exploitation of a person, you can be considered a trafficker (for example, a person driving the vehicle that transports the victims or the woman who cleans the room, house or apartment where the victims are

40 Guadalupe Correa-Cabrera \& Jennifer Bryson Clark, Re-victimizing Trafficked Migrant Women: The Southern Border Plan and Mexico's Anti-trafficking Legislation, 1 Eurasia Border REviEW 7, 61 (2016). 
kept could be defined as human traffickers) ${ }^{41}$ However, these two conditions constitute a different phenomenon and should not be equated to trafficking in persons as they currently are.

\section{Trafficking vs. Sexual Exploitation}

Critics of Mexico's General Law claim that the new law lacks precision in the language and is too complex to be consistently applied by authorities. Some also report that not focusing on force, fraud, or coercion has led public officials to target sex workers instead of concentrating on actual trafficking, with public officials conflating trafficking with prostitution. In fact, the 2012 law focuses primarily on sexual exploitation, and does not identify as trafficking victims those engaged in forced labor, forced begging, and compelled labor for criminal activities by organized crime. The anti-prostitution lobby heavily influenced the passage of the 2012 law, and while there is a growing awareness that trafficking in persons is not restricted to sex trafficking (including, for instance, labor trafficking), the majority of the law still remains focused on sexual exploitation.

Several human rights activists, practitioners and lawyers have recognized the adverse effects of the 2012 legislation on sex workers since it criminalizes prostitution to some extent. Such effects are the result of efforts by certain interest groups with particular agendas, including the aforementioned abolitionist groups. ${ }^{42}$

\section{Trafficking and Irregular Migration}

Mexico's current anti-trafficking legislation and its definition of trafficking in persons have also had negative effects on the irregular migrant population transiting through or settling in the country. According to Mónica Salazar, a leading legal expert on Mexico's anti-trafficking legislation and former director of the anti-trafficking NGO Colectivo contra la Trata de Personas

41 Prosecutors also classify as traffickers anyone who is aware, even if indirectly, that someone is a victim of trafficking and does not take action to stop the exploitation.

42 A good example of such group is the one headed by former Congresswoman Rosa María Orozco, who had key influence in the drafting of the law, which pushes for the criminalization of prostitution in the country. Orozco, who propelled herself into the political arena by promoting herself as an anti-trafficking activist and defender of Christian values, advocates that prostitution is a form of trafficking. Other anti-trafficking activists who also oppose prostitution - including Teresa Ulloa Ziaurriz, Regional Director of the Coalition Against Trafficking in Women and Girls in Latin America and the Caribbean (CATWLAC) - helped push for this broader definition of human trafficking and assisted Orozco's anti-prostitution efforts. 
(Collective against Trafficking in Persons), the significant rise in the number of arrests after the passage of the 2012 law that considers an overly broad definition of trafficking, along with the lack of conceptual understanding of this phenomenon by a number of law enforcement agents and judges, has hampered the correct identification of migrants who have been trafficked. ${ }^{43}$ This has resulted in re-victimization as unidentified migrant trafficking victims are frequently deported, or released and placed back in the hands of traffickers.

\section{The Transition Towards an Oral Adversarial System}

The country's legal system is an additional factor that has allowed ostensibly innocent individuals to be sentenced under human trafficking charges. Until very recently, Mexico applied the written inquisitorial legal system. Under this system, a judge made his/her decision based on written reports and the defendant was not allowed to address the judge nor confront his accusers. As a matter of fact, international observers often criticize Mexico for its courts' lack of transparency. ${ }^{44}$ The written inquisitorial system led defendants to be seen as presumptively guilty rather than individuals whose innocence must be presumed. In regard to trafficking cases, the government presumed that suspects were guilty until proven innocent. When prosecutors identified victims, they automatically started identifying people as traffickers, even if they lacked evidence. According to Salazar, "the government arrested over 1,000 individuals for trafficking under the previous approach of presumed guilt." She also noted that "in Mexico City, the government arrested more than 800 people," but clarified that "it has released more than half of them for lack of evidence." 45

The inquisitorial system sharply differs from the oral adversarial system used in the United States in which the prosecutor makes his case against the defendant to a jury, and which has now been adopted in Mexico. In 2008, Mexico approved constitutional reforms that included moving from the inquisitorial system to the oral adversarial system by 2016. Mexican states adopted the new system gradually, and the government expects that it will pro-

43 Guadalupe Correa-Cabrera \& Jennifer Bryson Clark, Re-victimizing Trafficked Migrant Women: The Southern Border Plan and Mexico's Anti-trafficking Legislation, 1 EuRASIA Border REview 7, 62 (2016).

44 Paul J. Zwier \& Alexander Barney, Moving to an Oral Adversarial System in Mexico: Jurisprudential, Criminal Procedure, Evidence Law, and Trial Advocacy Implications, 1 EMORY International LaW REview 26, 189 (2012).

45 Skype interview with Mónica Salazar, lawyer and former director of the anti-trafficking NGO Colectivo contra la Trata de Personas (Collective against Trafficking in Persons), (Mar. 10, 2017). She mentioned that this numbers vary according to different sources. Therefore, there is no way to provide definite statistics on these cases. 
Esta revista forma parte del acervo de la Biblioteca Jurídica Virtual del Instituto de Investigaciones Jurídicas de la UNAM

vide for fairer trials. Mexico's justice reforms present a positive opportunity for more just and transparent trials. By allowing defendants a fair chance to refute accusations, Mexico can better protect innocent individuals from being wrongly convicted. Nevertheless, as US-based experts have pointed out, the new system's implementation comes with its own set of shortcomings, including unsatisfactory police oversight and deficient respect to defendants' rights. ${ }^{46}$

Not only does Mexico's anti-trafficking legislation raise significant concerns, but how the country enforces it has also been problematic. One example is the Mexican state of Quintana Roo. According to official state government statistics, between 2010 and 2013, the Quintana Roo government started eight processes to investigate human trafficking. The government identified 32 people as trafficking victims but was unable to convict any perpetrators. "Those are extraordinarily low numbers, considering that Quintana Roo's largest city, Cancún, is an internationally-known hub for sex trafficking." ${ }^{47}$

A further problem is that state authorities have enforced anti-human trafficking laws unevenly. Congress drafted and adopted the 2012 General Law to ensure that states would investigate and prosecute human trafficking following federal norms and definitions. In fact, the current legislation requires Mexican states to adjust their anti-trafficking laws in accordance with the federal law. However, each state is allowed to legislate and prosecute trafficking as they see fit. According to Arun Kumar Acharya, a professor at Universidad Autónoma de Nuevo León, while most Mexican states have specific anti-trafficking laws based on the federal law, "many states" laws do not criminalize all forms of trafficking and these inconsistencies complicate interstate investigations, prosecutions, and convictions". ${ }^{48}$ Quintana Roo, again, illustrates this issue. Here the state legislature passed its own TIP law, but the Attorney General's Office (PGR) and the National Human Rights Commission $(\mathrm{CNDH})$ are currently contesting eleven of its articles. They claim the contested articles are inconsistent with the existing federal legislation and overlap the federal government's jurisdiction. ${ }^{49}$

${ }^{46}$ Bill Kisliuk, UCLA-led Study Highlights Shortcomings of Mexican Criminal Justice Reforms, UCLA Newsroom, (May 22, 2017, 5:43 PM), http://newesroom.ucla.edu/releases/ucla-led-studyhighlights-shortcomings-of-mexican-criminal-justice-reforms.

47 Guadalupe Correa-Cabrera \& Jennifer Bryson Clark, Re-victimizing Trafficked Migrant Women: The Southern Border Plan and Mexico's Anti-trafficking Legislation, 1 EURASIA BORDER REVIEW 7, 62-63 (2016).

$48 \mathrm{Ibid}, 61$.

49 The current imbroglio between federal and state authorities over TIP legislation in Quintana Roo has led some to believe that the state is not covered by any anti-trafficking law. This is an incorrect assumption. Even in the absence of a state legislation, the federal law still applies. 
Esta revista forma parte del acervo de la Biblioteca Jurídica Virtual del Instituto de Investigaciones Jurídicas de la UNAM

\section{Tapachula And the Effects of the 2012 General LaW}

As mentioned at the beginning of the present article, an illustrative case of the pitfalls of Mexico's definition of trafficking in persons and current anti-trafficking legislation is the city of Tapachula, located in Mexico's southernmost state of Chiapas. Situated just eleven miles from the border with Guatemala, the city has long been a hub for Central American migrants entering Mexico. Since 2006, when President Vincente Fox inaugurated a triage center for undocumented migrants known as Estación Migratoria Siglo XXI $\left(21^{\text {st }}\right.$ Century Migration Station) in the city, Tapachula has also become a convergence point for migrants in the process of being deported from Mexico. ${ }^{50}$

As an arrival and departure location for migrants, Tapachula is a focal point of exploitation of vulnerable Central Americans along Mexico's southern border. Unaccompanied Central American children selling crafts dot the city's downtown area, while girls from Guatemala, El Salvador, and Honduras work as waiters and prostitutes in shabby bars and brothels in Tapachula's marginalized quarters. The dire living conditions Central Americans face in Tapachula are not exclusive to the city, but a reflection of what migrants experience across the state of Chiapas. According to a 2014 report by the National Citizen Observatory of Justice and Legality (Observatorio Nacional Ciudadano de Seguridad, Justicia y Legalidad), Chiapas registered the second highest number of human trafficking cases in Mexico between 2010 and 2013. In 2013, the National Human Rights Commission (Comisión Nacional de los Derechos Humanos) listed Tapachula as one of Chiapas's high incidence zones of human trafficking. ${ }^{51}$

Tapachula-based human rights activists concur that human trafficking and exploitation take place in the city and that undocumented migrants are often victims of these crimes. For example, in 2012 Miriam González, a researcher at the Institute for Women in Migration (Instituto para las Mujeres en la Migración, IMUMI), reported that $58 \%$ of the women involved in the sex industry (or sex commerce) in Tapachula are of Guatemalan origin. According to González, $95 \%$ of these women are between the ages of 15 and 19 years old.$^{52}$ Gerardo Espinoza, an activist working at the Center of Human Rights Fray Matías de Córdova, informed us that trafficking for both labor and sexual exploitation

50 In 2015, Mexico deported 173,000 Central American migrants. Deborah Bonello, Mexico's Deportations of Central American Migrants are Rising, Los Angeles Times, (May 21, 2017, 6:51 PM), http://wwrw.latimes.com/world/mexico-americas/la-fg-mexico-migrants-20150905-story. html.

51 Comisión Nacional de los Derechos Humanos-México (CNDH), Diagnóstico sobre la Situación de la Trata de Personas en México, CNDH (2013).

52 It is not clear how she arrived at this figure. See La Hora (staff), Guatemaltecas en Tapachula son Obligadas a Prostituirse, LA HoRA, (May 21, 2017, 9:55 AM), http://lahora.gt/hemeroteca-lh/ guatemaltecas-en-tapachula-son-obligadas-a-prostituirse/. 
is a serious problem in Tapachula. Despite these crimes being recurrent in the city, Espinoza asserted that it is hard for the police to investigate cases of labor trafficking, as gathering substantive evidence is challenging.

Although it shares similar aspects with sex trafficking, including factors such as the commercialization of sex and a high incidence of Central American women, prostitution is not illegal in Mexico and migrant women often engage in it in order to afford their journey to the North. The complicated task of distinguishing between trafficking and prostitution or sex work is left to law enforcement and judicial authorities. Unfortunately, according to several human rights advocates interviewed for this research, these authorities are often unprepared and poorly versed in what distinguishes the two activities. The broad definition of human trafficking contained in the current legislation seems to further blur the line between them. Interviewed activists reported that exploited women and sex workers alike were arrested for human trafficking in Tapachula.

Tapachula authorities have recurrently conducted raids in bars long believed to serve as fronts for brothels where Central American women, including minors, are exploited. However, the law's broad definition of human trafficking has allowed the government to prosecute and sentence for trafficking individuals with tangential connections to human trafficking networks, including bar waiters, drivers, and even the victims themselves. The police seem to arbitrarily decide who are the trafficking victims and traffickers without conducting proper investigations. Those that the police accuses of trafficking are detained and allegedly forced through threats and coercion to admit that they were in charge of the raided bar. Fabricating confessions is not the only type of irregularity that local activists accuse officers of conducting in the city. Gerardo Espinoza claimed that police officers also extort migrant women who work in bars and brothels ${ }^{53}$ those who cannot pay the officers are arrested and even raped. His account included the story of an activist who denounced officers for such actions. The police accused the man of being a human trafficker, and he fled the city. Espinoza believes the man is innocent and told us thatit was a common practice among local corrupt officials to file bogus charges against their opponents.

It does not seem plausible that the migrant women jailed for human trafficking that we interviewed in Tapachula were the owners, partners or toplevel administrators of major sex trafficking rings. It was not evident either that they greatly benefited from this highly profitable illegal industry. ${ }^{54}$ Most of the testimonies we gathered at the prison depicted rather poor women,

53 Interview with Gerardo Espinoza, the Center of Human Rights Fray Matías de Córdova (Oct. 5, 2015), Tapachula, Chiapas.

54 Many of the women we met at the local prison were illiterate, and some of them alleged that they were promised to be freed as long as they signed some paperwork; they signed, but their release never happened. One woman said, for example, that she was forced into confessing a crime she did not commit after she witnessed her husband being beaten by the 
Esta revista forma parte del acervo de la Biblioteca Jurídica Virtual del Instituto de Investigaciones Jurídicas de la UNAM

who started a journey to the United States with the sole aim of providing a better life for their families. Some of them reported their concerns over their children, whom they left with relatives in their countries of origin. Their incarceration and alienation from the workforce placed a heavy financial burden on their families. Two of the inmates we interviewed did not even have enough money to make long distance phone calls to talk to their children on a frequent basis. Their extreme levels of vulnerability, as well as their lack of social networks and knowledge of Mexico's territory, would have made it extremely difficult for them to operate a human trafficking ring, or to even participate in the regular activities of such complex organizations.

Some of the human rights violations we witnessed in Tapachula were to some extent a consequence of lawmakers' desire to protect human trafficking victims, which ultimately blurred the legal line between victims and perpetrators. The 2012 legislation was drafted as an attempt to further prevention, protection, and prosecution of trafficking in persons in the country; however, the new law contributed to generating unexpected collateral problems, such as the ones we observed in Tapachula.

\section{RECOMMENDATIONS FOR REFORM}

There are reasons for mild optimism regarding Mexican anti-trafficking efforts. In October 2016, Mexico's Senate approved amendments to the 2012 anti-trafficking law that would have aligned it more closely with international law, but such reforms remained under consideration in the Chamber of Deputies. ${ }^{55}$ In December of the same year, the Mexican Congress approved a Crime Victim's Law, "which includes but is not limited to trafficking victims; and mandates the creation of a federal fund for crime victim assistance and mandates the states also create such funds" ${ }^{56}$ On February 8, 2017, the lower house of the Mexican Congress hosted a "Preventing Human Trafficking" forum, where members of the Congress's Special Commission on Trafficking in Persons, National Commission on Human Rights (CNDH), and Inter-Secretarial Commission on Trafficking in Persons discussed avenuesto improve the country's anti-trafficking legislation. ${ }^{57}$

At this last event, Congresswoman Julieta Fernández Márquez (PRI), president of the Special Commission on Trafficking in Persons, declared that "it is urgent [for Mexico] to adopt a law that truly pinpoints the origins of the

police. More than half of the women in prison accused of human trafficking were migrants from Central America.

55 U.S. Department of State, Trafficking in Persons Report, U.S. Department of State (2017).

56 Ibid. 279.

57 Veracruzanos.info (staff), Crece delito de trata: uno de cada 7 adolescentes ha recibido ofertas sexuales por internet, VERACRUZANOS.INFO (Feb. 9, 2017, 3:47 AM), http://veracruzanos.info/crecedelito-de-trata-uno-de-cada-7-adolescentes-ha-recibido-ofertas-sexuales-por-internet/. 
Esta revista forma parte del acervo de la Biblioteca Jurídica Virtual del Instituto de Investigaciones Jurídicas de la UNAM

problem and takes into consideration the living situation of [human trafficking] victims." ${ }^{58}$ According to Congressman César Camacho Quiroz (PRI), lawmakers have a duty to "craft an anti-trafficking legislation that is adequate, judicially solid, and efficient." 59 In February 2017, the President of the Chamber of Deputies, Congressman Javier Bolaños Aguilar (of the National Action Party, PAN), stated that reforming the country's anti-trafficking legislation should be a priority to all political parties in Mexico. ${ }^{60}$ Despite lawmakers' willingness to reform and amend the 2012 legislation, their aims are sometimes at odds with what some experts believe would be an adequate legal framework.

Believing that the 2007 stricter definition of human trafficking inhibited the government's ability to identify and prosecute traffickers, Mexican lawmakers downgraded the means of human trafficking, i.e. coercion, abduction, fraud, deception, and abuse of power, from an essential component of the crime to an aggravating factor. However, as Mexico's authorities still lack a clear and proper procedure to identify traffickers, they are unable to assert that all individuals they have apprehended for trafficking have indeed committed the crime, or have been victims of trafficking. Notwithstanding this fact, Mexican lawmakers do not seem inclined to reclassify means of trafficking as an essential component of the crime. Instead, they are focusing on expanding the list of acts that fall under the human trafficking conceptual umbrella. Critics claim that merely expanding the list of crimes that can be prosecuted as trafficking would not only be insufficient to combat trafficking, but it would also contribute to prosecuting as human traffickers people who did not commit trafficking.

Mónica Salazar believes that a more efficient approach would be to craft concise legislation that explicitly and accurately defines the fundamental components of human trafficking. In her words, lawmakers should focus on defining human trafficking as the crime of "exploiting a person, by any means, in order to benefit from said exploitation." From a conceptual standpoint, according to Salazar, the sort of exploitation a person is submitted to, including forced labor and sexual servitude, is irrelevant to determine if a crime constitutes human trafficking. Currently, Article 10 of the 2012 legislation specifically lists eleven forms of exploitation that Mexico understands as constituents of trafficking. ${ }^{61}$

58 Chamber of Deputies, Traslado de seres humanos de un lugar a otro con fines de explotación sexual o laboral, Delito de Lesa Humanidad, Bulletin 3024, Government of Mexico (Aug. 3, 2017, 10:24 AM). http://wrew5.diputados.gob.mx/index.php/camara/Comunicacion/Boletines/2017/Febrero/08/ 3024-Traslado-de-seres-humanos-de-un-lugar-a-otro-con-fines-de-explotacion-sexual-o-laboral-delito-delesa-humanidad.

59 Id.

60 Diputados llaman a dar celeridad a reformas contra trata de personas, Noticias TerRa, (May 22, 2017, 4:16 PM), http://wrww.20minutos.com.mx/noticia/190581/0/diputados-llaman-a-dar-celeridada-reformas-contra-trata-de-personas/

61 Skype interview with Mónica Salazar (Mar. 10, 2017). 
Salazar also pointed to Articles 23 and 40 of the current law as problematic. Article 23 lists the conditions under which compelled labor will not be considered forced labor nor labor exploitation. Its section 4 lists "labor done by members of local, national, or international organizations for the benefit of civil society groups or associations and private or public benefit institutions." This definition encompasses work done by religious organizations as well as NGOs. Given that some church shelters and NGOs have been suspected of exploiting migrants and other vulnerable groups, this exemption is particularly concerning. Article 40 does not distinguish between underage and adult individuals, stating that regardless of a victim's age or how he/she was exploited, a victim's consent will not preclude the perpetrator from penal responsibility. By ignoring consent given by adults, the current legislation denies individuals' judicial rights and agency.

According to Salazar, a more efficient law would be based on four main guidelines. First, rather than listing specific forms of exploitation, it should provide a concise definition of human trafficking in accordance with the one presented in the Palermo Protocol, including defining means as an essential component of trafficking. Second, Mexican authorities must have a complete understanding of what constitutes human trafficking in order to effectively define and combat it. Third, the new legislation should clearly recognize the agency of adults regarding consent. Fourth, lawmakers should draft the law pragmatically, without including clauses sanctioning other crimes and activities, such as labor exploitation and prostitution. ${ }^{62}$

\section{Conclusion}

In conclusion, from a conceptual standpoint, Mexico's 2012 anti-trafficking law provides a broad definition of trafficking in persons that does not include force, fraud, and coercion as essential elements of trafficking, but merely as aggravating factors to it. Such a definition allows Mexican authorities to investigate and condemn individuals for human trafficking even if, following internationally-adopted definitions, they have not committed this crime. The current anti-trafficking legislation in Mexico has in fact led to the misidentification of victims and perpetrators. It has also led to the re-victimization of the former, as we were able to ascertain in our visit to Tapachula's women prison. What is more, with the current approach to prosecution of human trafficking crimes in Mexico, more people are identified as traffickers. The higher the number of identified traffickers, the greater the funding antitrafficking agencies and organizations receive. Anomalies in Mexico's justice system are thus strengthened by these perverse incentives.

Although Mexico's anti-trafficking efforts, including crafting anti-trafficking laws and creating a special prosecutor's office to investigate and fight hu-

${ }^{62}$ Skype interview with Mónica Salazar (Mar. 10, 2017). 
man trafficking across the country must be acknowledged and praised, the many existing shortcomings in Mexico's legislative framework and justice system, in general, must be equally recognized and criticized. In many instances, the Mexican government has acted against the interests and security of the trafficking victims it is required to protect. Abuse and negligence were recurring themes in the field research we conducted. Under the current legislative framework, Mexican authorities have essentially prosecuted those who are in direct contact with victims of exploitation, rather than those who are "in charge" or who benefit from exploitation.

As Mónica Salazar stated: "The government should conduct proactive investigations. It should investigate who is in charge of the trafficking rings; who is the second in charge; who is responsible to watch over the victims; who assaults them; who threatens them; who forces them into debt, etc. Responsibilities and crimes must be differentiated. The government does not often proceed in this way because it would increase the complexity of investigations." In fact, under the current legislative scheme, we do not know who is really benefitting from trafficking. It is fair to assume that some of those benefitting the most from human trafficking networks likely have links with government authorities or influential members of the business community. However, most of the time these high-level connections are not correctly identified and the real beneficiaries of the big businesses of human trafficking are never investigated, arrested, or tried. The most vulnerable are those who very frequently end up in jail, paying the consequences of a limited justice system and deficient legal framework.

By removing the means from the definition of trafficking in persons, "prostitution, and other forms of sexual exploitation are synonymous with forced prostitution (trafficking)," thus making it difficult to identify the real victims and actual traffickers. ${ }^{64}$ Groups that support this idea - mostly abolitionists or anti-prostitution advocates - believe that by eliminating prostitution, sex trafficking is eliminated (see Appendix 1). However, in reality, this does not seem to be the case. Prostitution might involve the consent of all implicated parties, while sex trafficking necessarily involves a victim. Hence, it is important to make a clear distinction between prostitution and trafficking. In this way, sex workers will be allowed to work within legal parameters and will become less vulnerable. These actions might not end violence and exploitation, but will plausibly decrease them.

The implementation of the 2012 General Law, which inaccurately conceptualizes trafficking in persons, has also created stark divisions among government actors and civil society groups, thus generating further problems and

\footnotetext{
63 Skype interview with Mónica Salazar (Mar. 10, 2017).

${ }^{64}$ Guadalupe Correa-Cabrera \& Jennifer Bryson Clark, Re-victimizing Trafficked Migrant Women: The Southern Border Plan and Mexico's Anti-trafficking Legislation, 1 EuRASIA BORDER REVIEW 7, 55-70 (2016).
} 
Esta revista forma parte del acervo de la Biblioteca Jurídica Virtual del Instituto de Investigaciones Jurídicas de la UNAM

hampering collaboration among the different actors interested in fighting this high-level crime. ${ }^{65}$ There have been some important recent efforts to reform the current anti-trafficking legislation. In 2013 the Mexican Senate initiated a process of legislative reform with the aim of minimizing the risk of detaining and punishing innocent people. This proposal attempts to recover the key elements of internationally-adopted definitions of trafficking in persons by reincorporating the "means" and thus requiring evidence of subjugation. The proposed reform also aims to harmonize the standards for victims' protection with the contents of Mexico's General Law for Victims (Ley General de Victimas). ${ }^{66}$ Unfortunately, this reform has been stuck in the Chamber of Deputies for four years. Specific interest groups have influenced such actions, with abolitionist or anti-prostitution NGOs taking the lead to stop this reform. ${ }^{67}$

The broader definition of human trafficking present in the 2012 legislation has negative implications for Mexico's anti-trafficking efforts. It diverges from internationally-adopted definitions and covers a wide array of non-trafficking crimes and activities under its umbrella. Although Mexican law enforcement agencies criticized the 2007 anti-trafficking legislation for being too focused on the details of what constitutes human trafficking and for consequently resulting harder to apply, the far-reaching scope of the current definition misdirects and misapplies anti-trafficking efforts and funds. Mexico must adopt a definition that better describes the phenomenon of trafficking in persons. It must also develop and follow a program to ensure that government officials clearly understand what constitutes human trafficking.

\section{Appendix: Prostitution and Human Trafficking: A Historical Debate}

The definition of human trafficking formulated in the United Nations Protocol to Prevent, Suppress, and Punish Trafficking in Persons, Especially Women and Children of 2000 is the most influential conceptualization of trafficking in contemporary times. Its characterization of human trafficking as an activity consisting of means, purpose, and actions has influenced the draft of subsequent anti-trafficking legislation by national legislatures. However, despite the Palermo Protocol's near-universal adoption with its 172 party states, the process of drafting its definition of human trafficking was not the product of consensus, but the result of a compromise between clashing views

65 Hispanics in Philanthropy (HIP), Una mirada desde las organizaciones de la sociedad civil a la trata de personas en México, Hispanicis in Philanthropy, 9 (2017).

66 See: Chamber of Deputies, Ley General de Victimas, Última Reforma DOF 03-01-2017, Government of Mexico (May 22, 2017; 7:25 PM). http://wwweconocer.gob.mx/templates/conocer/ modulos_conocer/pdf/LET\%20GENERAL\%20DE\%20ViCTIMAS.pdf.

67 Hispanics in Philanthropy (HIP), Una mirada desde las organizaciones de la sociedad civil a la trata de personas en México, Hispanics in Philanthropy, 11 (2017). 
on what constitutes trafficking. The ongoing debate in Mexico on whether human trafficking is an illicit activity that covers primarily sexual exploitation of women and children, including prostitution, or a crime that includes other forms of exploitation such as forced labor and services is a centuries-old discussion that was at the center of the protocol's drafting process.

Following resolution 53/111 of December 9, 1998, the United Nations General Assembly established an Ad Hoc Committee, open to all states, in order to begin drafting what would become the Convention against Transnational Organized Crime. The committee met in Vienna eleven times between January of 1999 and the General Assembly adoption of the convention in November 2000. By analyzing the travaux préparatoires of the convention and its three protocols, it is possible to observe the evolution of the protocol against human trafficking going from one that focused primarily on the sexual exploitation of women and children to the definition currently in place, which does not discriminate victims based on sex, age, or type of exploitation suffered.

Produced in the first session of the Ad Hoc Committee, which took place from January 19 to 29, 1999, the first draft of the protocol against human trafficking was titled "Draft Protocol to Combat International Trafficking in Women and Children supplementary to the United Nations Convention on Transnational Organized Crime" (emphasis added). Its purpose was "to prevent, investigate and prosecute trafficking in persons for the purpose of forced labor, prostitution or other sexual exploitation, giving particular attention to the protection of women and children, who are so often the victims of organized crime." During its second session, from March 8 to 12, 1999, the Committee incorporated changes to the draft based on proposals made by Argentina and the United States. The Argentine delegation wanted to restrict the definition of trafficking to women and children while the American delegation desired to expand the definition to encompass other victims as well.$^{68} \mathrm{By}$ the third session, "almost all countries expressed their preference that the Protocol address all persons rather than only women and children, although particular attention should be given to the protection of women and children." 69

The debates in Vienna over what activities should be considered trafficking, if sexual exploitation should be the primary concern, and whether prostitution should count as a form of trafficking were not restricted to states. In her 2005 article titled "Now You See Her, Now You Don't: Sex Workers at the UN Trafficking Protocol Negotiation," Dr. Jo Doezema, a sex worker

68 As recorded in footnote 1 of "Revised Draft Protocol to Prevent, Suppress, and Punish Trafficking in Women and Children, Supplementing the Convention against Transnational Organized Crime, Combined Proposed Drafts of Argentina and the United States of America." United Nations Document Symbol A/AC.254/4/Add.3/Rev.1.

69 Footnote 2 of "Revised Draft Protocol to Prevent, Suppress and Punish Trafficking in Persons, Especially Women and Children, Supplementing the United Nations Convention against Transnational Organized Crime." United Nations Document Symbol A/AC.254/4/ Add.3/Rev.2. 
Esta revista forma parte del acervo de la Biblioteca Jurídica Virtual del Instituto de Investigaciones Jurídicas de la UNAM

rights activist and scholar, described lobby from both pro-prostitution and anti-prostitution feminist organizations during the two years of negotiations in Vienna that resulted in the trafficking protocol. In her words, "The lobby efforts were split into two 'camps', deeply divided in their attitudes towards prostitution. One lobby group, the Human Rights Caucus, saw prostitution as legitimate labor. The other, led by the Coalition Against Trafficking in Women (CATW), saw all prostitution as a violation of women's human rights". ${ }^{70}$ This divide between states as well as between feminist activists on how, if in any way, prostitution is connected to human trafficking, dates back to the inception of the concept of human trafficking in international law.

Drafted in 1902 and signed in 1904 by sixteen states, the "International Agreement for the Suppression of the White Slave Traffic" was the first international accord on human trafficking. Advocacy by anti-prostitution movements, known as abolitionists, in England, Western Europe, and the United States propelled the treaty. ${ }^{71}$ Josephine Butler, one of the main women's rights activist of Victorian Britain, actively campaigned for the criminalization of prostitution. She collaborated with journalist W.T. Stead, the author of multiple reports of British girls and women being sold into prostitution abroad, in helping to disseminate the "white slavery" panic of the late $19^{\text {th }}$ century. $^{72}$ Abolitionist activists did not believe that any woman would voluntarily choose to be a sex worker, and thus would only be in such a position if she had been forced or coerced.

In its first article, the 1904 treaty states that "Each of the Contracting Governments undertakes to establish or name some authority charged with the coordination of all information relative to the procuring of women or girls for immoral purposes abroad." The role of consent is not mentioned. In 1921, the League of Nations included the traffic of boys into the agreement and in 1949 the "United Nations Convention for the Suppression of Traffic in Persons and the Exploitation of the Prostitution of Others" declared that "prostitution and the accompanying evil of the traffic in persons for the purpose of prostitution are incompatible with the dignity and worth of a human person and endanger the welfare of the individual, the family, and the community of a person". ${ }^{73}$

\footnotetext{
70 Jo Doezema, Now You See Her, Now You Don't: Sex Workers at the UN Trafficking Protocol Negotiation, 1 Social \& Legal Studies 14, 62 (2005).

71 Elzbieta M. Gozdziak \& Elizabeth Collett, Research on Human Trafficking in North America: A Review of Literature, 1-2 International Migration 43, 100 (2005).

72 University of Toronto Libraries, Legislating the 'White Slave Panic,' 1885-1914, UnIVERsITY of Toronto, (Nov. 26, 2017, 6:36 PM), https://exhibits.library.utoronto.ca/exhibits/show/bawdy/ white-slave-trade.

73 Elzbieta M. Gozdziak \& Elizabeth Collett, Research on Human Trafficking in North America: A Review of Literature, (1-2) International Migration 34, 100-101 (2005).
}

Received: July 13th, 2017.

Accepted: October 17th, 2017. 